\title{
A Study of Chinese College Students' English Learning Motivation
}

\author{
Bei Zhang1, Xinguang Shao ${ }^{*}$ \\ ${ }^{1}$ School of Foreign Languages, University of Jinan, Jinan, China \\ ${ }^{2}$ Major in Applied Linguistics, Jinan, China \\ Email: *sfl_shaoxg@ujn.edu.cn
}

How to cite this paper: Zhang, B., \& Shao, X. G. (2021). A Study of Chinese College Students' English Learning Motivation. Open Journal of Social Sciences, 9, 273-279. https://doi.org/10.4236/jss.2021.97019

Received: June 24, 2021

Accepted: July 19, 2021

Published: July 21, 2021

Copyright $\odot 2021$ by author(s) and Scientific Research Publishing Inc. This work is licensed under the Creative Commons Attribution International License (CC BY 4.0).

http://creativecommons.org/licenses/by/4.0/

\begin{abstract}
Learning motivation is a kind of inner impetus to drive students' English learning. It can be classified into intrinsic and extrinsic motivation, integrative and instrumental motivation. According to the study, Chinese College Students' intrinsic learning motivation should be strengthened in English learning. This study offers some ways of boosting students' intrinsic motivation.
\end{abstract}

\section{Keywords}

Chinese College Students, English Learning, Motivation Questionnaire, Confidence, Interest in Learning English

\section{Introduction}

With the development of economy, English learning has become more and more important in China. Accordingly, many people put much emphasis on English teaching and it is a natural thing to associate a student's knowledge of English with his learning motivation. David says that the relationship between motivation and learning is complementary and in most cases, it is one person' motivation to arouse him to take action in study. Now studying students' motivation in their learning is becoming the focus in many researches. It has been found that learning motivation can stimulate the students' learning interest and improve their learning efficiency. Since having motivation is a key factor of students' achieving success in their English learning, English teachers should try to put the motivation theory into their teaching, helping their students obtain excellent achievements.

This paper aims to find out the factors which affect English learning motivation in China and provide some theoretical guidance for teachers' English 
teaching. A questionnaire is used in order to obtain the relevant data directly. The researcher analyzes the data about each item on motivation in college students' English learning on the basis of the statistics which is got from the questionnaire.

\section{Literature Review}

In Longman Dictionary of Contemporary English, motivation is defined as people's eagerness and willingness to do something without needing to be told or forced to do it.

Gardner and Lambert (1972) defines motivation as a combination of effort and desire to achieve the purpose of language learning. He thinks motivation includes some interior factors and power like individual intention and desire to stimulate people to take action. Only with the strong and correct learning motivation can learners have excellent performance in their study. So learning motivation is one of the key factors which may directly facilitate people's success in second language learning.

According to the current analysis, motivation is usually classified into two pairs. Those are intrinsic and extrinsic motivation, integrative and instrumental motivation. Harter (1981) divides motivation into intrinsic motivation and extrinsic motivation. Learners' intrinsic motivation can be fostered by their natural interest; while their extrinsic motivation is influenced by some external factors, such as the given reward, promotion and the opportunity of receiving further education. It is important for students to make the two learning motivations compatible and complimentary to each other in the learning process.

Deci and Ryan (1985) believe that intrinsic motivation plays a significant role in students' language learning. It is easy for many students to gain a good learning performance if their intrinsic motivation is developed, such as having curiosity and interest in their study.

Extrinsic motivation is usually considered as something that can undermine intrinsic motivation. It is believed by many people that students would lose their natural intrinsic interest if they are forced to do something to meet some extrinsic requirements. In language teaching teachers should give priority to the stimulation of students' intrinsic motivation in the teaching procedure.

Cook (1996: p. 68) thinks integrative motivation refers to the desire to be like and interact with speakers of the target language, while the instrumental motivation may be defined as the desire to acquire a language in order to attain utilitarian goals such as getting a job, furthering a career, reading or translating technical materials in target language, etc. Ellis (1999) thinks that integrative motivation may work with instrumental motivation to serve as a powerful predictor of people's success in doing their jobs. In second language learning, instrumental motivation refers to the students' desire to obtain some rewards like the opportunity to study overseas. If some learners don't have many chances to communicate with foreigners, their instrumental motivation in second language learning will become stronger than those who have. 
Some experts have put forward their theories of motivation. These theories include the social-education theory, three-level motivational construct theory and social cognitive theory.

Gardner and Lambert (1972) introduces the social-education model of motivation. He points out that learning a language is different from learning other subjects. In addition, foreign language learning is influenced by four variable factors. Those are social circumstance, individual difference, learning atmosphere and learning achievement. If students learn a foreign language in a specific social and cultural environment, their learning achievement will be affected undoubtedly by different cultural factors.

Dornyei (1994) introduces the three-level motivational construct theory. It consists of three levels. The first is language level which involves integrative motivation and instrumental motivation in language learning. The second is learner level involving some factors which include a learner's desire for success, language anxiety and self-efficiency. The third level is learning situation in the two aspects: students' interest in courses and the relationship between the courses and individual needs.

According to social cognitive theory, human behavior is a dynamic and reciprocal interaction of personal factors, behavior and the environment (Bandura, 1986). The cognitive view of motivation in language learning pays much attention to the process of making decision which is mainly about such issues as why people decide to do something and what factors influence the choices.

According to these theories of motivation, learners should know the significance of motivation in language learning and try to stimulate their motivation.

\section{A Research Report}

This study is conducted to explore the effects of motivation on Chinese college students' English learning with the help of questionnaires and interview. This part starts from a brief introduction to the study. Then, the data analysis is presented.

\subsection{Research Purpose}

In this paper, a questionnaire is used to investigate the learning motivation of college students in English learning. It is hoped that people may have a better understanding of the relationship between students' motivation and their learning achievements. Also, it is expected that the study may help people to find some strategies which may be applied to enhance students' motivation in language learning.

\subsection{Subjects}

The subjects in the study are all college students from University of Jinan. 100 students are involved including 46 female students and 54 male students. Their ages are from 16 to 19 , with an average of 17.5. These students don't have many chances to communicate with English native speakers. 


\subsection{Instrument}

A questionnaire is used here. It consists of fifteen items, each one on a 5-point scale ranging from "strongly agree" (point 5) to "strongly disagree" (point 1), the middle point being neutral (point 3). All the students' scores on the fifteen items are analyzed in a computer with the Statistical Package for Social Science (SPSS 11.0).

\subsection{Data Collection}

The 100 questionnaires were distributed to the selected students on October 12, 2019 and then they were collected immediately after the students finished. After that, all the questionnaires were proved to be effective in validity. Finally, all the scores about Chinese college students' motivation in English learning were entered into a computer and dealt with SPSS (11.0).

\subsection{Results and Analysis}

All the items in the questionnaire can be classified into four types. The first type consists of Items 1 - 4 which are about integrative motivation. The second type consists of Items 5 - 8 which are about instrumental motivation. The third type consists of Items $9-12$ which are about extrinsic motivation. And the fourth type consists of Items $13-15$ which are about intrinsic motivation. This practice may help us know much about some kinds of English learning motivation of college students.

Firstly, the average of students' scores about integrative motivation is in a high level. Item 1 is "I want to live abroad for some years." ( $M=3.85)$. Item 2 is "I like to make many foreign friends." ( $\mathrm{M}=3.81)$. Attracted by the good educational conditions of some western countries, a lot of Chinese college students want to study abroad. Some interviewed students said that they were eager to make more foreign friends who could introduce foreign cultures to them. Item 3 and Item 4 may reflect students' insights into some western cultures. Item 3 is "I like to know about the cultures of some English-speaking countries." $(M=3.79)$. Item 4 is "English is an important language that can help me know more about the world." ( $M=3.82)$. These items may reflect that the integrative motivation has a lot of impact on college students' English learning.

Secondly, in the items about the instrumental motivation the students get the highest points among the four types. They are Items 5 to 8 . Item 5 is "Learning English well can make me more likely to be a postgraduate." $(\mathrm{M}=4.35)$. Item 6 is "Learning English well can help me get more chances to work in big companies." $(M=3.98)$. Item 7 is "Having good English may help me have better performances in many places" ( $M=3.93)$. Item 8 is "Being good in English may help me get more successes in life." $(\mathrm{M}=4.46)$. In the interview more than half of the students agree that learning English well is helpful in their work and life. So it can be seen that instrumental motivation plays a very important role in college students' English learning. 
Thirdly, in the items about the extrinsic motivation the students get some high points. Items 9 to 12 are involved in the part. Item 9 is "English is a compulsory course in college life and I have to do well in this course." $(M=3.86)$. Item 10 is "Learning English well can help me easier to pass TOEEF or IELTS" $(\mathrm{M}=3.32)$. For some students who want to study abroad, passing TOEEF or IELTS is very important. Item 11 is "I learn English hard because my parents ask me to do that" $(M=3.57)$. It can be seen that many students have realized that learning English well is their parents' expectation. Item 12 is "Having good English can make me get very competitive when looking for an ideal job." ( $\mathrm{M}=$ 4.14). As the society develops, most students think that having good English is very necessary when finding jobs. Therefore, the extrinsic motivation in students' English learning is also strong.

Finally, the average of intrinsic motivation is at a relatively low level. Item 13 to 15 focus on the intrinsic motivation to learn English. From this questionnaire I find that many students lack interest in learning English. The following items will support my point. "I want to be an English teacher." (Item 13, M = 3.14), "I like to show myself up in English classroom." (Item 14, M = 2.56), "I hope to speak English fluently." (Item 15, M = 2.81) Besides, by chatting with some students, I understand that many of them don't like the English classroom activity. That is to say, improper English teaching strategies affect high school students' learning interest. It is difficult for students to learn English well if their intrinsic motivation is not fostered. So it is important for teachers to develop proper and practical strategies to boost students' intrinsic motivation. From the perspective of development, students' intrinsic motivation should be strengthened.

From this study I find that many students lack intrinsic motivation in learning English. In other words, they learn English passively. As we all know, good learning motivation enables students to form good learning habits and achieve satisfactory effects. Thus, teachers should pay much emphasis to the ways of fostering students' intrinsic motivation.

\section{Pedagogical Implications}

Through the above analysis, it seems that many students are mainly instrumentally motivated in English teaching. Therefore, we should pay greater attention to boost their intrinsic motivation. That is to say, teachers should arouse and cultivate the students' learning interest in English teaching practice. In the following part, three methods of fostering students' learning motivation will be illustrated.

\subsection{Creating Relaxed Atmosphere in English Classroom}

To create a situation is an effective way of cultivating students' ability in learning, especially in second language learning. At the beginning of an English class, teachers should try to create a good atmosphere in order to seize the attention of their students. A relaxed classroom atmosphere can make the students dare to express their ideas and show themselves without worrying about making mis- 
takes. Only by adopting the flexible teaching methods and establishing a harmonious and relaxed classroom atmosphere can the students be willing to learn English.

In the teaching process, a teacher is an organizer. His responsibility is to create good situations in which students can do their best. It is very important for English teachers to set up real situations and form the interactions between them and students. For example, teachers can let the students imitate the classic segments of some classical English films, which can help them know more about foreign cultures and customs. This method may stimulate students' learning interest and enhance their class participation.

\subsection{Giving Students Appropriate Praise}

As we all know, the evaluation on students' learning outcome can foster their learning motivation and play a significant role in their learning progress. Giving them moderate praise is more effective than criticism and intrinsic motivation may be aroused by doing this. It is not easy for teachers to give their students appropriate praise. In the teaching process, teachers should allow students to make mistakes. Meanwhile, for those who are in inferior positions in competition, teachers are supposed to give them some encouragement and concern and try to set some specific situations in which students can get the sense of success.

\subsection{Establishing Harmonious Relations between Teachers and Students}

Establishing the democratic and harmonious relations between teachers and students is a necessary condition of implementing the new curriculum reform. In such a good environment teachers and students can get along well with each other. The requirements for establishing the good relations between teachers and students include the following points.

Firstly, teachers should try to understand their students, including their family backgrounds, ages, personalities, etc. In the teaching practice, teachers can let students write some English compositions with titles like "Introduce Myself", "My Hobbies" and so on. Teachers can also make full use of their spare time to chat with students through QQ or Wechat as good friends do.

Secondly, teachers should love students with all their hearts because love is the greatest power in the world. They may give timely help to the students who are in need. Teachers' love can help students do well in study and encourage them to try to achieve their goals.

Last but not least, all the students have the same right to receive good education. But it is known that students' characteristics vary a lot from one to another. Teachers should respect all the students that have different personalities and treat them with the same attitude.

\section{Conclusion}

Learning motivation is a kind of inner impetus to drive students' study, which is 
also a requirement to prompt students in their study. It can be classified into intrinsic and extrinsic motivation, integrative and instrumental motivation. There are many factors which affect students' motivation of English learning, such as social factors and learners' attitudes. With the help of questionnaire and interview, we have a better understanding of college students' English learning motivation and also come to a conclusion that their intrinsic learning motivation should be strengthened. What's more, owing to these findings, some useful pedagogical implications are also put forward to improve the teaching quality. First of all, teachers should create a relaxed atmosphere in English classroom, for the relaxed classroom atmosphere will help reduce students' anxiety and increase their learning efficiency. Secondly, teachers should give students appropriate praise and punishment in teaching practice. Only in this way can students feel a sense of success. Thirdly, teachers should establish a good relationship with students. This study offers some ways of boosting students' intrinsic motivation.

\section{Conflicts of Interest}

The authors declare no conflicts of interest regarding the publication of this paper.

\section{References}

Arnold, J. (2000). Affect in Language Learning. Beijing: Foreign Language Teaching and Research Press.

Bandura, A. (1986). Social Foundations of Thought and Action: Social Cognitive Theory. Englewood Cliffs: Prentice Hall.

Cook, V. (1996). Second Language Learning and Language Teaching. Edward Arnold, London.

Deci, E. L., \& Ryan, R. M. (1985). Intrinsic Motivation and Self-Determination in Human Behaviour. New York: Plenum. https://doi.org/10.1007/978-1-4899-2271-7

Dornyei, Z. (1994). Motivation and Motivating in the Foreign Language Classroom. The Modern Language Journal, 3, 273-284. https://doi.org/10.1111/j.1540-4781.1994.tb02042.x

Dornyei, Z. (1998). Motivation in Second and Foreign Language Learning. Language Learning, 31, 117-135. https://doi.org/10.1017/S026144480001315X

Ellis, R. (1999). Understanding Second Language Acquisition. Shanghai: Shanghai Foreign Language Education Press.

Gardner, R. C., \& Lambert, W. E. (1972) Attitudes and Motivation in Second Language Learning. London: Edward Arnold.

Harter, S. (1981). A New Self-Report Scale of Intrinsic versus Extrinsic ORIENTATION in the Classroom: Motivation and Information Components. Development Psychology, No. 7, 300-312. 